\title{
ASSESSMENT OF ECOLOGICAL AND GEOCHEMICAL CONDITION OF SOILS AND DUST CONTENT OF ATMOSPHERIC AIR IN THE RESIDENTIAL ZONE OF THE MINING INDUSTRY CENTER
}

(C) 2018

Khasanova Rezeda Firgatovna, doctor of biological sciences, leading researcher

of Ecology and Environmental Management Laboratory; associate professor of Natural Sciences Department

Semenova Irina Nikolaevna, doctor of biological sciences, senior researcher

of Ecology and Environmental Management Laboratory; professor of Natural Sciences Department

Sibay Branch Institute of Strategic Studies of Republic of Bashkortostan

(Sibay, Republic of Bashkortostan, Russian Federation); Sibay Institute (Branch) of Bashkir State University

(Sibay, Republic of Bashkortostan, Russian Federation)

Rafikova Yuliya Samigullovna, candidate of biological sciences, senior researcher of Ecology and Environmental Management Laboratory

Sibay Branch Institute of Strategic Studies of Republic of Bashkortostan

(Sibay, Republic of Bashkortostan, Russian Federation)

Suyundukov Yalil Tukhvatovich, doctor of biological sciences, chief researcher

of Ecology and Environmental Management Laboratory; deputy director for scientific work

Sibay Branch Institute of Strategic Studies of Republic of Bashkortostan

(Sibay, Republic of Bashkortostan, Russian Federation); Sibay Institute (Branch) of Bashkir State University (Sibay, Republic of Bashkortostan, Russian Federation)

Ilyina Irina Valerievna, candidate of biological sciences, associate professor of Botany Department

Sibay Institute (Branch) of Bashkir State University (Sibay, Republic of Bashkortostan, Russian Federation)

Abstract. The research studies the content of heavy metals (HM) in soils of residential zones of Sibay - the mining industry center of the South-East of the Republic of Bashkortostan. It is shown that in soils under herbaceous vegetation there is an increased content of a number of HMS, such as copper, zinc and cadmium. At the same time the areas located under the crown of Betula pendula Roth. are less contaminated with HM compared to open areas. Reduced content of a number of metals (iron, cadmium, cobalt and mobile forms of Nickel) in soils under the crown of the Roth confirms the barrier role of woody plants that protect the soil from airborne toxicants. The study showed the prospects of using a birch as a type of accumulator-phytoremediant in the greening of the mining region urban areas of the Republic of Bashkortostan. Studies of TM content in organs and tissues have shown that representatives of the species growing in Sibay can accumulate a significant amount of phytotoxicants, especially zinc, the content of which ranged 1041-1855 mg/kg. One of the sources of the increased TM content in the leaves and the bark of trees is dust. The paper presents a comparative study of the dustiness of birch leaves growing in the Central part of the city with heavy traffic and in the vicinity of the Sibay quarry, developing a Deposit of copper-zinc ore. The amount of dust on the leaves collected near the dumps of the Sibay quarry was $3,53 \pm 0,64 \mathrm{~g} / \mathrm{m}^{2}$, which is less than in the Central part of the city, where this figure reached $41,04 \pm 10,38 \mathrm{~g} / \mathrm{m}^{2}$. Obviously, this is due to the fact that the dumps of the Sibay quarry are located in an open and intensively ventilated area, which explains the strong dispersion of dust. At the same time dust particles near the quarry dumps are much more contaminated with manganese, cobalt and cadmium than in the Central part of the city.

Keywords: heavy metals; pollutants; maximum permissible concentration; regional geochemical background; mining industry; dust content of atmospheric air; environmental monitoring; soils; woody plants; birch; herbaceous vegetation; Sibay; Republic of Bashkortostan.

УДК 574.52

DOI 10.24411/2309-4370-2018-14125

Статья поступила в редакцию 03.07.2018

\section{АНАЛИЗ СТЕПЕНИ РЕАГИРОВАНИЯ ГИДРОБИОНТОВ НА СОДЕРЖАНИЕ ХИМИЧЕСКИХ ВЕЩЕСТВ} В ВОДЕ ВЕРХНЕГО И СРЕДНЕГО ТЕЧЕНИЙ РЕКИ БЕЛОЙ (РЕСПУБЛИКА БАШКОРТОСТАН) (C) 2018

\author{
Чаус Борис Юрьевич, кандидат биологических наук, доцент кафедры биологии \\ Стерлитамакский филиал Башкирского государственного университета \\ (2. Стерлитамак, Республика Башкортостан, Российская Федерация)
}

Аннотащия. В статье приводится анализ биоиндикационных возможностей гидробионтов различных си-
стематических категорий для оценки и прогноза антропогенного загрязнения реки Белой (верхнего и средне-
го течений) в ходе экологического мониторинга природных вод Республики Башкортостан. Сбор гидробион-
тов и анализ встречаемости (в долях единицы) 30 видов беспозвоночных животных из отрядов Ругатіdеl-
loida, Littorinimorpha, Pulmonata, Plecoptera, Ephemeroptera, Trichoptera и 12 видов высшей водной paститель-
ности проводился с 2005 по 2017 годы в районах 10 государственных водных постов на реке Белой. В каче-
стве гидрохимических показателей на изученных створах использовались данные из ежегодных Государ-
ственных докладов «О состоянии природных ресурсов и окружающей среды Республики Башкортостан» по 144 Самарский научный вестник. 2018. Т. 7, № 4 (25) 
среднегодовому содержанию соединений марганца, никеля и железа, нефтепродуктов, фенолов, азота аммонийного, меди и цинка за период исследований. Выявлена статистически достоверная корреляция между встречаемостью ряда водных организмов и химическими веществами и их соединениями, определяемыми в воде реки Белой, и на основе линейных регрессионных моделей впервые построен индикационный ряд гидробионтов по степени снижения их реагирования на содержание химических веществ в изученном водотоке. Подобный подход, очевидно, можно использовать для разработки рекомендаций по использованию биологических анализов при выявлении химических веществ, влияющих на водную фауну и флору, что очень важно для принятия технологических решений по очистке сточных вод, сбрасываемых в реку Белую, протекающую по территории Республики Башкортостан.

Ключевые слова: биоиндикация; мониторинг; водные моллюски; личинки Plecoptera; личинки Ephemeroptera; личинки Trichoptera; высшая водная растительность; река Белая; постоянство видов; гидрохимические показатели; корреляционный и регрессионный анализы; биологический анализ вод; индикационный ряд.

\section{Введение}

Качество воды р. Белая - крупного (протяженность 1420 км) левобережного притока р. Кама формируется под влиянием сточных вод предприятий жилищно-коммунального хозяйства, черной металлургии, химической, нефтехимической, нефтедобывающей, лесозаготовительной, деревообрабатывающей, машиностроительной и металлообрабатывающей отраслей экономики, а также смывов с территорий предприятий, сельхозугодий и населенных пунктов Республики Башкортостан.

Контроль качества воды в р. Белой в настоящее время осуществляется в основном посредством химических и физико-химических методов в 10 пунктах, 21 створе, 25 вертикалях [1-7]. Но только такой подход не в состоянии дать полную характеристику вредного действия антропогенных факторов на водную биоту. Последнее обстоятельство требует внедрения в оценку качества природных вод биологических методов (биоиндикация и биотестирование), для реализации которых разработано большое количество индексов и приемов, хорошо проанализированных в работах [8-10] и в ряде других публикаций. Однако большинство из используемых показателей заканчиваются констатацией уровня загрязнения водного объекта по принципу - «чисто», «грязно» и т.д., но проблема влияния химических загрязняющих веществ на водную флору и фауну остается открытой. Решение этой проблемы, по-видимому, будет возможным лишь при объединении гидрологических, физико-химических и биологических подходов, используемых в ходе экологического мониторинга вод. Создание долговременных региональных баз данных не только по результатам гидрологических и гидрохимических, но и гидробиологических исследований в районах государственных водных постов (а не на произвольно выбранных участках рек) позволит выявить региональные индикаторные виды и степень их реагирования на сбрасываемые в воды химические вещества и их соединения.

Перспективными объектами для гидробиологического мониторинга являются водные моллюски [1113], личинки Plecoptera [14], Ephemeroptera [15-17], Trichoptera [18-22] и высшая водная растительность [23]. Изучение постоянства гидробионтов в р. Белой в последнее время носило эпизодический характер, и, как следствие, результатами этих работ были относительно обобщенные сведения по индикационным качествам гидробионтов [24].

Цель данной работы - анализ степени реагирования водных беспозвоночных животных и представителей высшей водной растительности для биоинди- кационных исследований в системе экологического мониторинга р. Белой (Республика Башкортостан).

В задачи исследования входило:

1) изучение встречаемости гидробионтов в районах 10 государственных водопостов, находящихся в верхнем и среднем течениях р. Белой;

2) сопряженный анализ связи динамики встречаемости изученной водной биоты с гидрохимическими показателями.

\section{Материал и методы исследования}

Исследования на р. Белой проводились в летнюю межень с 2005 по 2017 гг. в районах 10 государственных водопостов (створах) - районы ж/д станции «Шушпа» (C1: 54,09682705285799 с.ш., $58,4999227538037^{\circ}$ в.д.) и ДО «Арский камень» (C2: 53,86115788200094 ․ш., 58,268351554870605 ${ }^{\circ}$ в.д.), выше (С3: 52,8538947271166 с.ш., 55,937232971191406 ․д.) и ниже (C4: 52,97880342779925 ${ }^{\circ}$ с.ш., 55,977959632873535 ${ }^{\circ}$ в.д.) города Мелеуза, выше города Салавата (C5: 53,32222881321969 ${ }^{\circ}$ с.ш., $\quad$ 55,99103808403015 в.д.), ниже города Ишимбая (C6: 3,446659922791845 с.ш., 56,01332187652588 в.д.), выше (C7: 53,625248198285 ${ }^{\circ}$ с.ш., $56,021175384521484^{\circ}$ в.д.) и ниже (C8: 53,72393550850673ㅇ․․, 56,087104082107544우․д.) города Стерлитамака, ниже поселка Прибельский (С9: 54,39540102929409 с.ш., 56,4561653137207 в.д.) и выше города Уфы (C10: 54,649889889274036 с.ш., 55,9978723526001 в.д.).

На каждом створе сбор гидробионтов осуществлялся в соответствии с [25] на 10-ти участках (расстояние между участками $\approx 100-150$ м). Определение видовой принадлежности водных организмов проводилось непосредственно на створах. Определение водных беспозвоночных проводилось по Определителю пресноводных беспозвоночных России и сопредельных территорий [26-28]. Определение высшей водной растительности проводилось по Определителю высших растений Башкирской АССР [29; 30].

В качестве гидрохимических показателей использовались данные по среднегодовому содержанию в речных водах соединений марганца $(\mathrm{Mn})$, никеля (Ni) и железа $(\mathrm{Fe})$, нефтепродуктов $(\mathrm{H} / \Pi)$, фенолов (Фен), азота аммонийного $\left(\mathrm{NH}_{4}\right)$, меди $(\mathrm{Cu})$, цинка $(\mathrm{Zn})$. Все вышеуказанные гидрохимические показатели ежегодно публикуются в Государственном докладе «О состоянии природных ресурсов и окружающей среды республики Башкортостан» (20062017).

Для статистической обработки материала использовалась прикладная программа Microsoft Excel. Нормальность распределения показателя встречаемости гидробионтов на створах проверялась по кри- 
Чаус Б.Ю.

Анализ степени реагирования гидробионтов на содержание химических веществ в воде...

03.02.00 - общая биология

терию Шапиро - Уилки в программе Statistica 10. Сила связи между встречаемостью гидробионтов и показателями содержания в водах химических веществ и их соединений оценивалась по коэффициенту корреляции Пирсона. Проведение регрессионного анализа и интерпретация осуществлялись на калькуляторе онлайн-сервиса сайта Математического форума Math Help Planet [31]. Все статистические расчеты проводились при уровне значимости 0,05 (95\%).

\section{Результаты исследований и их обсуждение}

В ходе исследований было использовано 30 видов водных беспозвоночных животных и 12 видов выс- ших водных растений (ВВР) (табл. 1), легко определяемых визуально и включенных в компьютеризированную базу данных [32]. Анализ динамики встречаемости видов переднежаберных моллюсков на биотопах р. Белой с 2005 по 2016 годы выявил, что относительным постоянством на изученных створах характеризуются $B$. troschelii и $B$. inflate, что говорит о приспособлении этих гидробионтов к экологическим условиям на участках реки с разным качеством воды.

Встречаемость других видов гастропод, а особенно V. pulchella и V. piscinalis, характеризуется значительной динамикой по годам исследований (рис. 1).

Таблица 1 - Систематическая принадлежность гидробионтов, использованных в ходе исследования

\begin{tabular}{|c|c|c|c|}
\hline Класс & Отряд & Семейство & Вид \\
\hline \multirow{9}{*}{ Gastropoda } & \multirow{3}{*}{ Pyramidelloida } & \multirow{3}{*}{ Valvatidae } & Valvata pulchella Studer, 1820 \\
\hline & & & Valvata piscinalis O.F. Müller, 1774 \\
\hline & & & Valvata cristata O.F. Müller, 1774 \\
\hline & \multirow{6}{*}{ Littorinimorpha } & \multirow{4}{*}{ Bithyniidae } & Bithynia tentaculata L., 1758 \\
\hline & & & Bithynia leachii Sheppard, 1823 \\
\hline & & & Bithynia troschelii Paasch, 1842 \\
\hline & & & Bithynia inflata Hansen, 1845 \\
\hline & & \multirow{2}{*}{ Viviparidae } & Viviparus viviparus L, 1758 \\
\hline & & & Viviparus contectus Millet, 1813 \\
\hline \multirow{21}{*}{ Insecta } & \multirow{7}{*}{ Plecoptera } & \multirow{2}{*}{ Nemouridae } & Nemurella pictetii Klapalek, 1900 \\
\hline & & & Nemoura cinerea Retzius, 1783 \\
\hline & & \multirow{2}{*}{ Chloroperlidae } & Xanthoperla apicalis Newman, 1836 \\
\hline & & & Siphonoperla burmeisteri Pictet, 1841 \\
\hline & & Taeniopterygidae & Taeniopteryix nebulosa L., 1758 \\
\hline & & \multirow{2}{*}{ Leuctridae } & Leuctra nigra Olivier, 1811 \\
\hline & & & Leuctra fusca L, 1758 \\
\hline & \multirow{7}{*}{ Ephemeroptera } & \multirow{2}{*}{ Siphlonuridae } & Siphlonurus linnaeanus Eaton, 1871 \\
\hline & & & Siphlonurus aestivalis Eaton, 1903 \\
\hline & & \multirow{3}{*}{ Baetidae } & Cloeon dipterum L., 1758 \\
\hline & & & Cloeon luteolum Muller, 1776 \\
\hline & & & Baetis tricolor Tschernova, 1928 \\
\hline & & \multirow{2}{*}{ Heptageniidae } & Ecdyonurus venosus Fabricius, 1775 \\
\hline & & & Heptagenia sulphurea Muller, 1776 \\
\hline & \multirow{7}{*}{ Trichoptera } & Goeridae & Silo pallipes Fabricius, 1781 \\
\hline & & Lepidostomatidae & Lepidostoma hirtum Fabricius, 1775 \\
\hline & & Phryganeidae & Phryganea bipunctata Retzius, 1783 \\
\hline & & \multirow{4}{*}{ Limnaphilidae } & Chaetopteryx villosa Fabricius, 1798 \\
\hline & & & Halesus interpunctatus Zetterstedt, 1840 \\
\hline & & & Anabolia soror McLachlan, 1875 \\
\hline & & & Grammotaulius atomaris Fabricius, 1798 \\
\hline \multicolumn{4}{|c|}{ Высшая водная растительность } \\
\hline \multirow{10}{*}{ Liliopsida } & & Alismataceae & Sagittaria sagittifolia L., 1753 \\
\hline & & Butomaceae & Butomus umbellatus L., 1753 \\
\hline & & \multirow{2}{*}{ Hydrocharitaceae } & Elodea canadensis Michx., 1803 \\
\hline & & & Najas marina L., 1753 \\
\hline & & \multirow{4}{*}{ Potamogetonaceae } & Potamogeton natans L., 1753 \\
\hline & & & Potamogeton perfoliatus L., 1753 \\
\hline & & & Potamogeton crispus L., 1753 \\
\hline & & & Stuckenia pectinata L., Börner, 1912 \\
\hline & & \multirow{2}{*}{ Araceae } & Lemna minor L., 1753 \\
\hline & & & Spirodela polyrhiza Schleid., 1839 \\
\hline \multirow{2}{*}{ Magnoliopsida } & & Haloragaceae & Myriophyllum spicatum L., 1753 \\
\hline & & Ceratophyllaceae & Ceratophyllum demersum L, 1753 \\
\hline
\end{tabular}




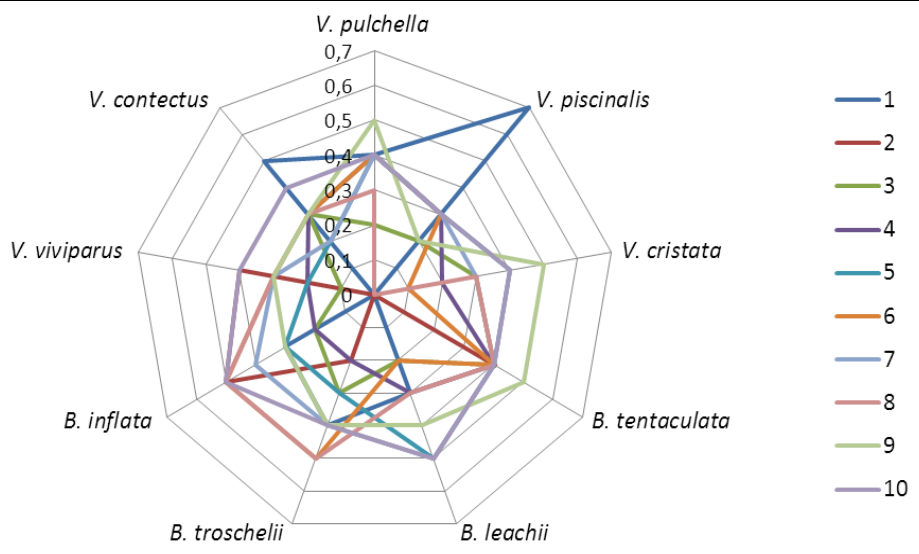

Рисунок 1 - Динамика среднего постоянства видов Gastropoda на створах (1-10) р. Белой за период с 2005 по 2016 гг.

Изучение динамики постоянства личинок веснянок на биотопах верхнего и среднего течений р. Белой с 2005 по 2016 годы показало, что относительно постоянна лишь личинка L. nigra, что свидетельству- ет об адаптации этого вида к разным экологическим условиям. Встречаемость личинок C. apicalis, T. nebulosa, N. pictetii, N. cinerea, L. fusca u S. burmeisteri динамична по годам исследований (рис. 2).

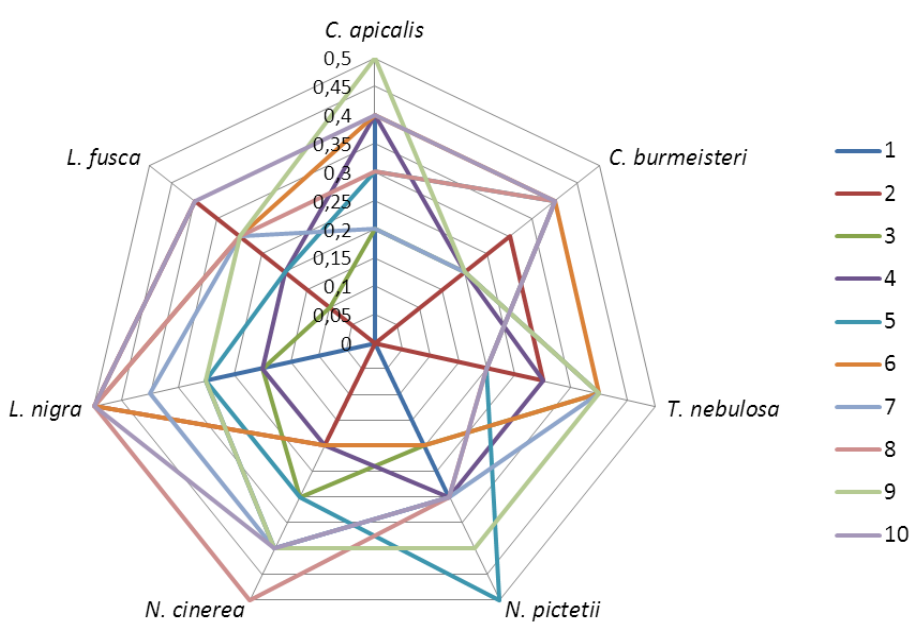

Рисунок 2 - Динамика среднего постоянства видов Plecoptera на створах (1-10) р. Белой за период с 2005 по 2016 гг.

Анализ динамики встречаемости личинок поденок в верхнем и среднем течении р. Белой за период с 2005 по 2016 годы показал, что относительным постоянством на изученных створах обладает лишь C. dipterum. Исходя из этого можно сделать вывод, что данный вид является космополитом в характеризуемом регионе. Встречаемость же личинок других видов поденок (S. linnaeanus, S. aestivalis, C. luteolum, B. tricolor, E. venosus, H. sulphurea) обладает значительной динамикой по годам исследований (рис. 3), что, по-видимому, можно объяснить влиянием на личинок этих видов экологических условий в изученных районах р. Белой.

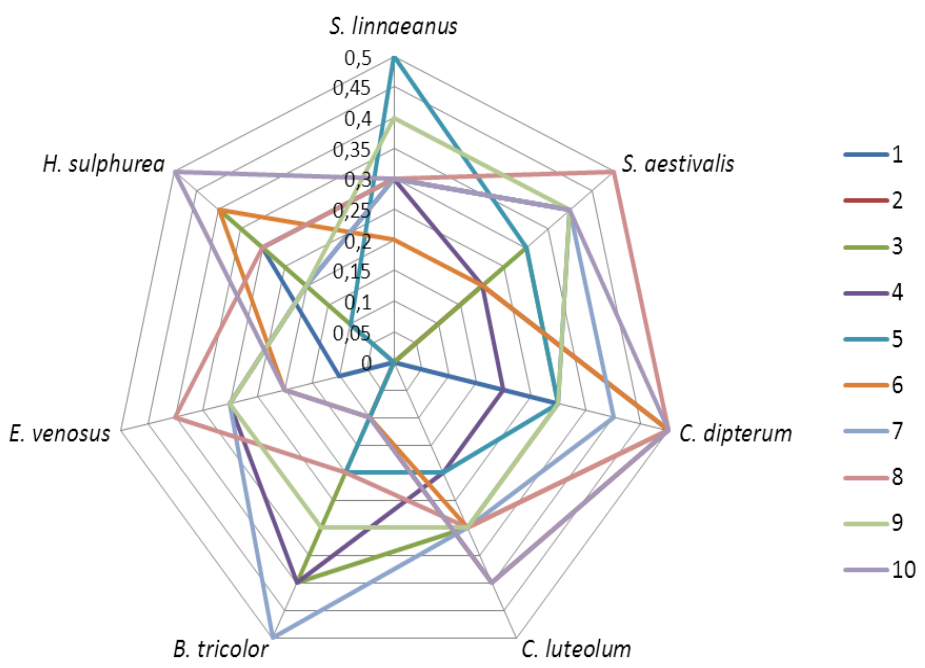

Рисунок 3 - Динамика среднего постоянства видов Ephemeroptera на створах (1-10) р. Белой за период с 2005 по 2016 гг. 
Чаус Б.Ю.

Анализ степени реагирования гидробионтов на содержание химических веществ в воде..

03.02.00 - общая биология

Исходя из анализа динамики постоянства личинок ручейников на изученных створах р. Белой с 2005 по 2016 годы, можно отметить, что относительным постоянством характеризуются лишь H. interpunctatus и A. soror. Другие виды ручейников, а особенно S. pallipes, обладают значительной динамикой постоянства по годам исследований (рис. 4).

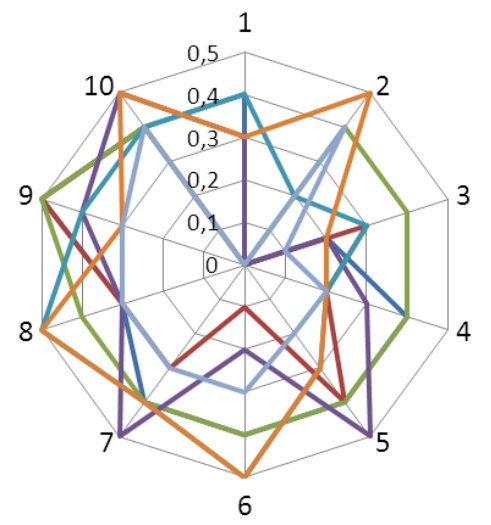

При анализе реагирования высшей водной растительности на качество воды р. Белой в ее верхнем и среднем течениях можно отметить, что относительно стабильное постоянство на всех изученных створах за годы исследований было характерно лишь для L. minor (рис. 5).

Рисунок 4 - Динамика среднего постоянства видов личинок Trichoptera на створах (1-10) р. Белой за период с 2005 по 2016 гг.

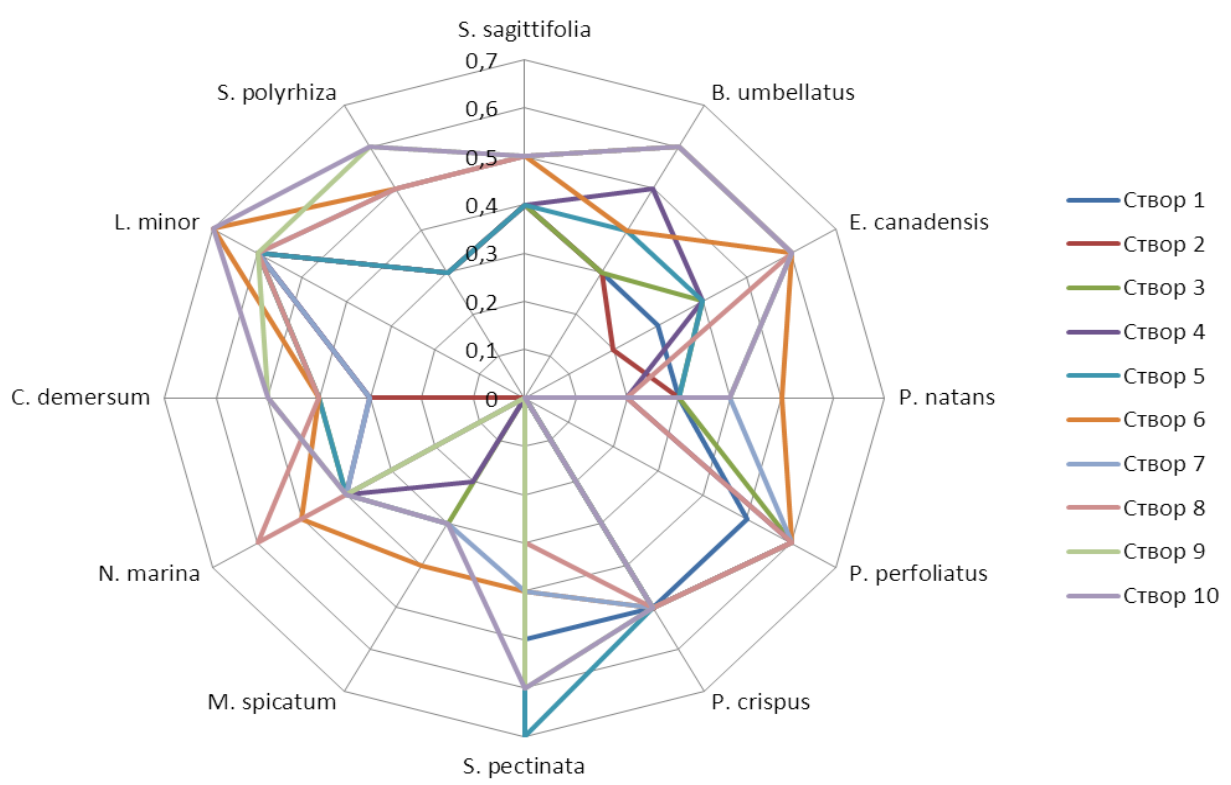

Рисунок 5 - Динамика среднего постоянства видов высшей водной растительности на створах (1-10) р. Белой за период с 2005 по 2016 гг.

Данное обстоятельство, по-видимому, связано с повышенным содержанием биогенных веществ в данном водотоке.

Анализ корреляционных связей между встречаемостью гидробионтов показал, что с повышением содержания поллютантов в воде на некоторых изученных участках р. Белой наблюдалось увеличение встречаемости ряда видов.

Так, при повышении содержания меди увеличивалась встречаемость V.piscinalis (р-н ж/д станции «Шушпа»), фенолов - B. troschelii (ниже г. Мелеуз) и P. bipunctata (р-н ДО «Арский камень» и ниже г. Ишимбай), соединений марганца - B. troschelii (выше г. Салавата) и V. macrostoma, личинок S. pallipes (район ж/д станции «Шушпа»), C. apicalis и B. tricolor и H. interpunctatus (ниже г. Ишимбай), соединений железа - C. burmeisteri и C. apicalis (ниже г. Ишимбай и выше г. Стерлитамака, соответственно), S. aestivalis (выше г. Стерлитамака), A. soror (ниже г. Ишимбай) и C. villosa (выше г. Стерлитама- ка), на P.perfoliatus, N. marina и L. minor (ниже г. Стерлитамака), нефтепродуктов - C. luteolum (ниже п. Прибельский), S. pallipes (ниже п. Прибельский), B. umbellatus, C. demersum (р-н ДО «Арский камень») и P. lucens (ниже г. Ишимбай).

Снижение же встречаемости отмечалось для B. leachii, N. cinerea, N. pictetii, S. aestivalis, A. soror, P. bipunctata, P. pectinatus и M. spicatum при повышении содержания фенолов (ниже г. Мелеуз), нефтепродуктов (ниже г. Стерлитамака, ниже п. Прибельский, ниже г. Ишимбай и выше г. Уфы) (табл. 2).

Как уже было выше отмечено, постоянство видов ВВР, а особенно E. canadensis u S. pectinate, в р. Белой обладает значительной динамикой. Такие виды BBP, как S. sagittifolia, B. umbellatus, P. natans, P. perfoliatus, $P$. crispus, $S$. pectinalis, $C$. demersum и $S$. polyrhiza, можно охарактеризовать с позиций добавочных видов в реке (рис. 6). Такой вид, как M. spicatum, на ряде створов можно охарактеризовать с позиций добавочного и случайного вида, что также, по- 
Чаус Б.Ю. 03.02.00 - общая биология Анализ степени реагирования гидробионтов на содержание химических веществ в воде...

видимому, связано с экологическими условиями на изученных створах (грунт, скорость течения, химическое загрязнение и т.п.).

А.П. Садчиков и М.А. Кудряшов [33] отмечают, что N. marina и P.pectinalis характерны для хлоридных вод. Массовое же развитие рясковых, по их мнению, указывает на неблагополучие в экосистеме. Обилие таких растений, как L. minor и S. polyrhiza, помимо эвтрофирования, свидетельствует о сельскохозяйственном загрязнении поверхностных вод, а многокоренник способен развиваться на концентрированных стоках животноводческих комплексов. О наличии антропогенного воздействия на водные экосистемы свидетельствует и пышное развитие S. sagittifolia, E. canadensis, C. demersum и M. spicatum.

По результатам корреляционного анализа связей между постоянством видов ВВР и содержанием в водах загрязняющих веществ можно отметить, что в основном отмечается стимуляция $(r=0,7-0,9)$ увеличения встречаемости водных растений при увеличении концентрации ряда поллютантов, содержащихся в воде на ряде изученных участках р. Белой (табл. 2).

Таблица 2 - Корреляционно-регрессионные связи между постоянством гидробионтов и гидрохимическими показателями р. Белой в районах исследования

\begin{tabular}{|c|c|c|c|c|c|c|c|}
\hline \multirow{2}{*}{$\mathrm{Y}$} & \multirow{2}{*}{$X$} & \multirow{2}{*}{$\mathrm{r}$} & \multirow{2}{*}{ УР } & \multirow{2}{*}{$\mathrm{R}^{2}$} & \multicolumn{2}{|c|}{$\mathrm{F}$} & \multirow{2}{*}{$\mathrm{A}, \%$} \\
\hline & & & & & $F_{\text {факт, }}$ & $F_{\text {табл, }}$ & \\
\hline \multicolumn{8}{|c|}{ Район ж/д станции «Шушпа» } \\
\hline \multicolumn{8}{|l|}{ Ручейники } \\
\hline S. pallipes & $\mathrm{Mn}$ & 0,73 & $Y=0,04 x+0,12$ & 0,53 & 8,74 & 5,12 & 19,2 \\
\hline \multicolumn{8}{|c|}{ Переднежаберные моллюски } \\
\hline V. piscinalis & $\mathrm{Cu}$ & $-0,73$ & $Y=-0,11 X+0,56$ & 0,53 & 11,38 & 4,97 & 18,70 \\
\hline \multicolumn{8}{|c|}{ Район дома отдыха «Арский камень» } \\
\hline \multicolumn{8}{|l|}{ Ручейники } \\
\hline P. bipunctata & Фен & 0,74 & $Y=0,12 x+0,28$ & 0,56 & 7,13 & 5,12 & 15,2 \\
\hline A. soror & $\mathrm{NO}_{2}$ & 0,74 & $Y=0,28 x+0,28$ & 0,56 & 7,72 & 5,12 & 19,4 \\
\hline \multicolumn{8}{|c|}{ Высшая водная растительность } \\
\hline B. umbellatus & $\mathrm{H} / \Pi$ & 0,76 & $Y=0,08 X+0,15$ & 0,59 & 14,10 & 4,97 & 24,18 \\
\hline C. demersum & $\mathrm{H} / \Pi$ & 0,83 & $\mathrm{Y}=0,07 \mathrm{X}+0,17$ & 0,69 & 22,02 & 4,97 & 22,34 \\
\hline \multicolumn{8}{|c|}{ Ниже города Мелеуз } \\
\hline \multicolumn{8}{|c|}{ Переднежаберные моллюски } \\
\hline B. leachii & Фен & $-0,73$ & $Y=-0,25 X+0,51$ & 0,53 & 10,44 & 5,12 & 16,50 \\
\hline B. troschelii & Фен & 0,74 & $\mathrm{Y}=0,40 \mathrm{X}+0,16$ & 0,56 & 11,48 & 5,12 & 30,58 \\
\hline \multicolumn{8}{|c|}{ Выше города Салават } \\
\hline \multicolumn{8}{|c|}{ Переднежаберные моллюски } \\
\hline B. troschelii & $\mathrm{Mn}$ & 0,73 & $\mathrm{Y}=0,06 \mathrm{X}+0,13$ & 0,53 & 11,21 & 5,00 & 13,25 \\
\hline \multicolumn{8}{|c|}{ Ниже города Ишимбай } \\
\hline \multicolumn{8}{|l|}{ Веснянки } \\
\hline X. apicalis & $\mathrm{Mn}$ & 0,74 & $Y=0,14 x+0,04$ & 0,56 & 12,14 & 5,12 & 11,0 \\
\hline S. burmeisteri & $\mathrm{Fe}$ & 0,74 & $Y=0,13 x+0,03$ & 0,56 & 12,12 & 5,12 & 11,0 \\
\hline \multicolumn{8}{|l|}{ Поденки } \\
\hline B. tricolor & $\mathrm{Mn}$ & 0,72 & $Y=0,04 x+0,03$ & 0,52 & 10,63 & 5,12 & 15,9 \\
\hline \multicolumn{8}{|l|}{ Ручейники } \\
\hline H. interpunctatus & $\mathrm{Mn}$ & 0,73 & $Y=0,06 x+0,06$ & 0,53 & 9,72 & 5,12 & 15,3 \\
\hline A. soror & $\mathrm{Fe}$ & 0,73 & $Y=0,10 x+0,12$ & 0,53 & 9,33 & 5,12 & 16,0 \\
\hline P. bipunctata & Фен & 0,84 & $Y=0,24 x+0,19$ & 0,71 & 20,72 & 5,12 & 15,3 \\
\hline Переднежаберны & юски & & & & & & \\
\hline V. macrostoma & $\mathrm{Mn}$ & 0,73 & $Y=0,06 X+0,06$ & 0,53 & 11,43 & 5,00 & 15,67 \\
\hline Высшая водная p & IьHOCI & & & & & & \\
\hline P. pectinatus & $\mathrm{Fe}$ & $-0,79$ & $Y=-0,06 X+0,59$ & 0,62 & 16,34 & 5,00 & 12,04 \\
\hline P. lucens & $\mathrm{H} / \Pi$ & 0,75 & $\mathrm{Y}=0,18 \mathrm{X}+0,03$ & 0,57 & 13,04 & 5,00 & 48,12 \\
\hline & & & ше города Стерлита & & & & \\
\hline Веснянки & & & & & & & \\
\hline X. apicalis & $\mathrm{Fe}$ & 0,73 & $Y=0,14 x+0,14$ & 0,53 & 8,93 & 5,12 & 16,3 \\
\hline Поденки & & & & & & & \\
\hline S. aestivalis & $\mathrm{Fe}$ & 0,74 & $Y=0,07 x+0,06$ & 0,56 & 7,04 & 5,12 & 27,0 \\
\hline Ручейники & & & & & & & \\
\hline C. villosa & $\mathrm{Fe}$ & 0,74 & $\mathrm{Y}=0,07 \mathrm{x}+0,25$ & 0,56 & 7,21 & 5,12 & 15,6 \\
\hline & & & же города Стерлита & & & & \\
\hline Веснянки & & & & & & & \\
\hline N. cinerea & $\mathrm{H} / \Pi$ & $-0,74$ & $Y=-0,24 x+0,73$ & 0,56 & 11,03 & 5,12 & 51,3 \\
\hline Ручейники & & & & & & & \\
\hline A. soror & $\mathrm{H} / \Pi$ & $-0,73$ & $Y=0,12 x+0,47$ & 0,53 & 7,73 & 5,12 & 16,6 \\
\hline
\end{tabular}


Чаус Б.Ю.

Анализ степени реагирования гидробионтов на содержание химических веществ в воде...

03.02 .00 - общая биология

\begin{tabular}{|c|c|c|c|c|c|c|c|}
\hline \multirow{2}{*}{$\mathrm{Y}$} & \multirow{2}{*}{$\mathrm{X}$} & \multirow{2}{*}{$\mathrm{r}$} & \multirow{2}{*}{ УР } & \multirow{2}{*}{$\mathrm{R}^{2}$} & \multicolumn{2}{|c|}{$\mathrm{F}$} & \multirow{2}{*}{$\mathrm{A}, \%$} \\
\hline & & & & & $F_{\text {факт, }}$ & $F$ табл, & \\
\hline \multicolumn{8}{|c|}{ Высшая водная растительность } \\
\hline P. perfoliatus & $\mathrm{Fe}$ & 0,67 & $Y=0,10 X+0,21$ & 0,45 & 8,15 & 5,00 & 17,25 \\
\hline N. marina & $\mathrm{Fe}$ & 0,75 & $Y=0,10 X+0,21$ & 0,57 & 18,08 & 5,00 & 12,56 \\
\hline L. minor & $\mathrm{Fe}$ & 0,88 & $\mathrm{Y}=0,15 \mathrm{X}-0,06$ & 0,77 & 32,91 & 5,00 & 14,64 \\
\hline \multicolumn{8}{|c|}{ Ниже посёлка Прибельский } \\
\hline \multicolumn{8}{|l|}{ Веснянки } \\
\hline N. pictetii & $\mathrm{H} / \Pi$ & $-0,73$ & $Y=-0,14 x+0,54$ & 0,53 & 8,42 & 5,12 & 40,8 \\
\hline \multicolumn{8}{|l|}{ Поденки } \\
\hline C. luteolum & $\mathrm{H} / \Pi$ & 0,74 & $\mathrm{Y}=0,04 \mathrm{x}+0,18$ & 0,56 & 10,53 & 5,12 & 18,8 \\
\hline S. aestivalis & $\mathrm{H} / \Pi$ & $-0,73$ & $Y=-0,07 x+0,56$ & 0,53 & 9,13 & 5,12 & 30,5 \\
\hline \multicolumn{8}{|l|}{ Ручейники } \\
\hline S. pallipes & $\mathrm{H} / \Pi$ & 0,73 & $\mathrm{Y}=0,06 \mathrm{x}+0,17$ & 0,53 & 10,42 & 5,12 & 20,6 \\
\hline P. bipunctata & $\mathrm{H} / \Pi$ & $-0,74$ & $\mathrm{Y}=-0,05 \mathrm{x}+0,48$ & 0,56 & 11,81 & 5,12 & 23,2 \\
\hline \multicolumn{8}{|c|}{ Выше города Уфы } \\
\hline \multicolumn{8}{|c|}{ Высшая водная растительность } \\
\hline M. spicatum & $\mathrm{Fe}$ & $-0,76$ & $Y=-0,18 X+0,49$ & 0,57 & 13,47 & 5,00 & 28,51 \\
\hline
\end{tabular}

Исходя из проведенных исследований с учетом коэффициента детерминации $\left(\mathrm{R}^{2}\right)$, составлен индикационный ряд встречаемости гидробионтов по степени убывания силы влияния поллютантов, содержащихся в воде р. Белой: L. minor (соединения железа ниже г. Стерлитамак, $\left.\mathrm{R}^{2}=0,77\right) \rightarrow P$. bipunctata $($ фенолы ниже г. Ишимбая, $\left.\mathrm{R}^{2}=0,71\right) \rightarrow C$. demersum (нефтепродукты в районе ДО «Арский камень», $\left.\mathrm{R}^{2}=0,69\right) \rightarrow C$. hirtus (медь в районе ж/д станции «Шушпа, $\left.\mathrm{R}^{2}=0,65\right) \rightarrow P$. pectinatus (соединения железа ниже г. Ишимбая, $\left.\mathrm{R}^{2}=0,62\right) \rightarrow K$. testudo (нефтепродукты ниже г. Мелеуза, $\left.\mathrm{R}^{2}=0,61\right) \rightarrow B$. umbellatus (нефтепродукты в районе ДО «Арский камень», $\left.\mathrm{R}^{2}=0,59\right) \rightarrow$ B. angularis (нефтепродукты ниже п. Прибельский, $\left.\mathrm{R}^{2}=0,58\right) \rightarrow P$. lucens (нефтепродукты ниже г. Ишимбай), N. marina (соединения железа ниже г. Стерлитамака), M. spicatum (соединения железа выше г. Уфы) $\left(\mathrm{R}^{2}=0,57\right) \rightarrow P$, bipunctata $u A$, soror (фенолы и азот нитритный в районе ДО «Арский камень»), B. troschelii (фенолы ниже г. Мелеуза), X. apicalis (соединения марганца ниже г. Ишимбая), S. burmeisteri (соединения железа ниже г. Ишимбая), S. aestivalis и C. villosa (соединения железа выше г. Стерлитамака), L. bulla и N. cinerea (нефтепродукты ниже г. Стерлитамака), C. luteolum и $P$. bipunctata (нефтепродукты ниже п. Прибельский) $\left(\mathrm{R}^{2}=0,56\right)$.

Для остальных изученных на предмет встречаемости в р. Белой гидробионтов - S. pallipes, V. piscinalis (район ж/д станции «Шушпа»), B. leachii (ниже г. Мелеуз), B. troschelii (выше г. Салават), B. tricolor, H. interpunctatus, A. soror, V. macrostoma (ниже г. Ишимбай), X. apicalis (выше г. Стерлитамак), A. soror, P. perfoliatus (ниже г. Стерлитамак), N. pictetii, S. aestivalis, S. pallipes (ниже п. Прибельский) в зависимости от содержания в воде химических веществ и их соединений коэффициент детерминации находился в диапазоне $\mathrm{R}^{2}=0,53-0,48$, что, очевидно, связано с влиянием неучтённых факторов.

\section{Заключение}

Таким образом, результаты исследований показали, что 23 вида из использованных в ходе исследований 30 видов беспозвоночных животных и 8 из 12-ти видов высшей водной растительности проявили от- ветную реакцию (динамика встречаемости) $(\mathrm{r}>0,7)$ на загрязнение р. Белой в ее верхнем и среднем течениях. На основании этого и с учетом коэффициента детерминации впервые составлен индикационный ряд гидробионтов по степени снижения их реагирования на содержание химических веществ в воде реки Белой.

Результаты исследования, очевидно, позволят проводить индикацию содержания в воде р. Белой химических веществ и осуществлять прогноз их содержания по показателю встречаемости гидробионтов. Так, например, по показателю встречаемости L. minor $\approx 0,1$ в р. Белой ниже г. Стерлитамака можно прогнозировать содержание соединений железа по лимитирующему рыбохозяйственному признаку вредности на уровне 1 ПДК (0,3 мг/л).

Исходя из проведенных биоиндикационных исследований, можно предположить, что такой подход позволит выявить наиболее влияющие на гидробионтов химические вещества и их соединения, что очень важно для принятия технологических решений по очистке сточных вод, сбрасываемых в реку Белую, протекающую по территории Республики Башкортостан.

\section{Список литературы:}

1. Государственный доклад «О состоянии природных ресурсов и окружающей среды республики Башкортостан в 2005 году». Уфа, 2006. 197 с.

2. Государственный доклад «О состоянии природных ресурсов и окружающей среды республики Башкортостан в 2006 году». Уфа, 2007. 200 с.

3. Государственный доклад «О состоянии природных ресурсов и окружающей среды республики Башкортостан в 2007 году». Уфа, 2008. 217 с.

4. Государственный доклад «О состоянии природных ресурсов и окружающей среды республики Башкортостан в 2008 году». Уфа, 2009. 200 с.

5. Государственный доклад «О состоянии природных ресурсов и окружающей среды республики Башкортостан в 2009 году». Уфа, 2010. 189 с.

6. Государственный доклад «О состоянии природных ресурсов и окружающей среды республики Башкортостан в 2010 году». Уфа, 2011. 343. 197 с. 
7. Государственные доклады «О состоянии природных ресурсов и окружающей среды республики Башкортостан» [Электронный ресурс] // Министерство природопользования и экологии Республики Башкортостан http://ecology.bashkortostan.ru/presscenter/ lectures.

8. Абакумов В.А., Сущеня Л.М. Гидробиологический мониторинг пресноводных экосистем и пути его совершенствования // Экологические модификации и критерии экологического нормирования: труды международного симпозиума. М., 1991. С. 41-51.

9. Булгаков Н.Г., Левич А.П., Максимов В.Н. Региональный экологический контроль на основе биотических и абиотических данных мониторинга // Экологический мониторинг: учебное пособие. Ч. 5 / под ред. проф. Д.Б. Гелашвили. Нижний Новгород: Изд-во Нижегородского университета, 2003. С. 93259.

10. Шитиков В.К., Розенберг Г.С., Зинченко Т.Д. Количественная гидроэкология: методы системной идентификации. Тольятти: ИЭВБ РАН, 2003. 463 с.

11. Гордзялковский А.В., Макурина О.Н. Водные моллюски - перспективные объекты для биологического мониторинга // Вестник СамГУ. Естественнонаучная серия. 2006. № 7 (47). С. 37-44.

12. Jozwiaik M.A., Jozwiaik M., Kozlowski R., Rabajczyk A. The role of indicator malacofauna in pollution assessment of inland water exposed to anthropopressure, the case of the Kielce Lake // Ecological chemistry and engineering. 2010. Vol. 17. № 4. P. 485-494.

13. Gupta S.K., Singh J. Evalution of mollusk as sensitive indicator of heavy metal pollution in aquatic system: a review // The II OAB Journal Special Issue on Environmental Management for Sustainable Development, 2011. Vol. 2, is. 1. P. 49-57.

14. Тесленко В.А. Веснянки (Plecoptera) в экосистемах рек Дальнего Востока России: автореф. дис. ... д-ра биол. наук. Владивосток, 2006. 44 с.

15. Боев В.Г., Баянов М.Г. Эколого-фаунистическая характеристика поденок и веснянок из водоемов Южного Урала // Фауна и экология насекомых Урала. Свердловск, 1987. С. 16-25.

16. Безматерных Д.М. Зообентос равнинных притоков Верхней Оби: монография / отв. ред. В.В. Кириллов. Барнаул: Изд-во Алт. ун-та, 2008. 186 с.

17. Потиха Е.В., Тиунова Т.М. Биоразнообразие поденок лесных заповедников Приморья (юг Дальнего Востока России) // Проблемы водной энтомологии России и сопредельных стран: мат-лы VI всерос. (с междунар. участием) симпозиума по амфибиотическим и водным насекомым, посв. памяти известного российского ученого-энтомолога Лидии Андреевны Жильцовой, Сев.-Осет. гос. ун-т им. К.Л. Хетагурова. Владикавказ: Изд-во СОГУ, 2016. С. 93-103.

18. Гигиняк И.Ю. Видовое разнообразие и биотопическая приуроченность личинок ручейников (Trichoptera) в озерных и речных экосистемах центральной и северной частей Беларуси // Проблемы водной энтомологии России и современных стран: мат-лы III Всероссийского симпозиума по амфибиотическим и водным насекомым. Воронеж: Издательско-полиграфический центр Воронежского государственного университета, 2007. С. 58-65.

19. Каплин В.Г. Биоиндикация состояния экосистем: учеб. пособие для студентов биол. специально- стей ун-тов и с.-х. вузов. Самара: Самарская ГСХА 2001. 143 c.

20. Лепнева С.Г. Личинки и куколки подотряда кольчатощупиковых (Annulipalpia). Фауна CCCP. Т. 2, вып. 1. М.-Л.: Наука, 1964. 563 с.

21. Иванов В.Д., Григоренко В.Н., Арефина А.Т. Отряд ручейники (Trichoptera) // Определитель пресноводных беспозвоночных России и сопредельных территорий. Т. 5. Высшие насекомые / под общ. ред. С.Я. Цалолихина. СПб.: Наука, 2001. С. 7-72.

22. Лавров И.А. Эколого-фаунистические особенности ручейников (Hexapoda: Trichoptera) бассейна реки Клязьмы: автореф. ... дис. канд. биол. наук. Владимир, 2011. 25 с.

23. Chaus B. Assessment of a bioecological condition of the Beloy River (Republic of Bashkortostan) on indexes of abundance of the highest water vegetation // The way of science. International scientific journal. № 11 (21). Volgograd: Publishing House «Scientific survey», 2015. Р. 35-39.

24. Чаус Б.Ю. Биоиндикация как подход к развитию прогнозирующего моделирования гидробиологических особенностей реки Белой (Россия. Республика Башкортостан) // European Applied Sciences: modern approaches in scientific researches. Papers of the 1st International Scientific Conference. December 17 19. Stuttgart. Germany, 2012. P. 12-14.

25. Руководство по гидробиологическому мониторингу пресноводных экосистем / под ред. В.А. Абакумова. СПб.: Гидрометеоиздат, 1992. С. 131-150.

26. Определитель пресноводных беспозвоночных России и сопредельных территорий / под общ. ред. С.Я. Цалолихина. Т. 6. Моллюски. Полихеты. Немертины. СПб.: Наука, 2004. 528 с.

27. Определитель пресноводных беспозвоночных России и сопредельных территорий. Т. 3. Паукообразные. Низшие насекомые. СПб.: Наука, 1997. 225 с.

28. Определитель пресноводных беспозвоночных России и сопредельных территорий. Т. 1. Низшие беспозвоночные. СПб., 1994. 202 с.

29. Определитель высших растений Башкирской АССР. Ч. 1 / Ю.Е. Алексеев, А.Х. Галеева, И.А. Губанов и др., отв. ред. Е.В. Кучеров, А.А. Мулдашев. М.: Наука, 1988. 316 с.

30. Определитель высших растений Башкирской АССР. Ч. 2 / Ю.Е. Алексеев, А.Х. Галеева, И.А. Губанов и др., отв. ред. Е.В. Кучеров, А.А. Мулдашев. М.: Наука, 1989. 375 с.

31. МНК и регрессионный анализ Онлайн + графики [Электронный ресурс] // Математический форум Math Help Planet. - http://mathhelpplanet.com/ static.php?p=onlayn-mnk-i-regressionniy-analiz.

32. Чаус Б.Ю. Базы данных для совершенствования экологического мониторинга рек Южного Урала // Актуальные проблемы науки и образования в современном вузе: мат-лы III междунар. науч.-практ. конф. 7-10 июня 2017 г. Ч. І / отв. ред. А.И. Филиппов. Стерлитамак: Стерлитамакский филиал БашГУ, 2017. C. 237-240.

33. Садчиков А.П., Кудряшов М.А. Геоботаника: Прибрежно-водная растительность: учебное пособие для студентов высших учебных заведений. М.: Издательский центр «Академия», 2005. 240 с. 


\section{THE DEGREE ANALYSIS OF HYDROBIONTS RESPONSE TO THE CONTENT OF CHEMICALS IN THE WATER OF THE UPPER AND MIDDLE REACHES OF THE BELAYA RIVER (REPUBLIC OF BASHKORTOSTAN)}

\section{(C) 2018}

Chaus Boris Yuryevich, candidate of biological sciences, associate professor of Biology Department Sterlitamak Branch of Bashkir State University (Sterlitamak, Republic of Bashkortostan, Russian Federation)

\footnotetext{
Abstract. The paper deals with the analysis of bioindicator opportunities of hydrobionts of various systematic categories that helps to assess and forecast anthropogenic pollution of the Belaya River (the top and average currents) during environmental monitoring of natural waters of the Republic of Bashkortostan. Hydrobionts were collected and the occurrence analysis (in unit shares) of 30 species of invertebrate animals from groups Pyramidelloida, Littorinimorpha, Pulmonata, Plecoptera, Ephemeroptera, Trichoptera and 12 species of the highest water vegetation was carried out from 2005 to 2017 in regions of 10 state water posts on the Belaya River. The data from annual State reports on the average annual content of compounds of manganese, nickel and iron, oil products, phenols, nitrogen ammoniyny, copper and zincum were used as hydrochemical parameters during the research. The reliable correlation between some water organisms with chemicals and their connections was defined in the water of the Belaya River. The author also constructs for the first time an indicator range of hydrobionts on decrease extent in their response to the chemicals content in the studied water. Similar approach can be used for recommendations development about the use of biological analyses while identifying the chemicals influencing water fauna and flora.

Keywords: bioindication; monitoring; water mollusks; larvae of Plecoptera; larva of Ephemeroptera; larva of Trichoptera; highest water vegetation; Belaya River; constancy of types; hydrochemical parameters; correlative and regression analyses; biological analysis of waters; indicator row.
} 